DOI 10.18551/rjoas.2021-08.04

\title{
THE EFFECT OF ENTREPRENEURIAL MENTAL ATTITUDES AND TECHNOPRENEURSHIP ON THE PERFORMANCE OF VILLAGE OWNED ENTERPRISES IN LOMBOK ISLAND
}

\author{
Hadi Samsul ${ }^{*}$, Master of Management \\ Faculty of Economics and Business, University of Mataram, Mataram, Indonesia \\ Suparman Lalu, Hermanto \\ Faculty of Economics and Business, University of Mataram, Mataram, Indonesia \\ *E-mail: shsamsul4@gmail.com
}

\begin{abstract}
The objectives of this study are: (1) Determine the effect of entrepreneurial mental attitudes on the performance of Village Owned enterprises (BUMDES) in Lombok Island; (2) Determine the effect of entrepreneurial mental attitudes on technopreneurship; (3) Determine the effect of Technopreneurship on the Performance of Village Owned Enterprises in Lombok Island. This type of research is causal associative. The data collection method uses a census. Respondents in this study were all directors of Village Owned enterprises on the Lombok Island, as many as 85 peoples. The data collection tool used in this study was a questionnaire. Data analysis using SEM-PLS. The results of the research and discussion above, the conclusions from the research that can be drawn are: (1) Entrepreneurial mental attitude has a positive and significant effect on the Performance of Village Owned Enterprises. (2) Entrepreneurial mental attitude has a positive and significant effect on the Technopreneurship. (3) Technopreneurship has a positive and significant effect on the performance of Village Owned enterprises.
\end{abstract}

\section{KEY WORDS}

Entrepreneurial mental attitudes, technopreneurship, performance.

The human resource aspect plays a very important role in an organization. Human resources are an inseparable part of the organization, which is one of the factors determining the success of the organization in achieving its goals. Human resources in a government agency or public service sector or organization are human resources that should be managed and developed to achieve the vision and mission set by the organization. The high quality of human resources is needed so that humans can play a role as reliable implementers in their organizational functions.

Performance is a description of the level of achievement of the implementation of an activity/program/policy in realizing the goals, objectives, vision, and mission of the organization as stated in the planning strategy of an organization (Mahsun, 2006). Performance can be known only if the individual or group of individuals has established success criteria. This success criterion is in the form of certain goals or targets to be achieved. Performance is the result of an evaluation of the work carried out by individuals compared to the criteria that have been set together. Two factors affect performance, namely: internal factors and external factors. Internal factors include attitudes, interests, intelligence, and motivation. While external factors are facilities, competence, salary, work atmosphere, and work environment (Sinambela, 2017).

The success of a business is determined by the characteristics of the attitudes and behavior of entrepreneurs. Entrepreneurial success and failure are strongly influenced by various factors, both external and internal. The success of a business is influenced by positive action in running its business, that action or behavior is influenced by the values of entrepreneurial personality as stated by Suryana (2006: 52), "namely the values of courage 
to face risk, positive attitude, optimism, courage, independent, able to lead, and willing to learn from experience. "

The entrepreneurial mental attitude is the result of the formation of character that will lead to the achievement of the goals of the business itself. According to Hartanti (2008), Entrepreneurial Mental Attitude is the life lived in entrepreneurship which is basically an entrepreneurial attitude and behavior shown through the nature, character, and character of a person who has a willingness to manifest innovative ideas into the real world creatively (Hartanti, 2008).

Previous researchers, namely Nurfitriya (2018) found that entrepreneurial attitudes have a positive and significant effect on the development of batik entrepreneurs at the center for batik handicrafts in the city of Tasikmalaya. In addition, research results from Octavia (2015) and Nurhayati et al (2012) found that The entrepreneurial attitude has a positive and significant effect on the success or business performance of the Cibaduyut Shoe Manufacturer, Bandung City.

In addition to affecting business performance, entrepreneurial attitudes can also affect entrepreneurial abilities such as technopreneurship. Technopreneurship, one part of the development of entrepreneurship, provides a picture of entrepreneurship using technologybased innovation. The technopreneur concept is based on a technology base that is used as an entrepreneurial tool. Technopreneurship comes from a combination of the words "technology" and "entrepreneurship" (Depositario, et al, 2011). Another opinion states that Technopreneurship is a process in an organization that prioritizes innovation and continuously finds the main problems of the organization, solves problems, and implements problem-solving methods to increase competitiveness in the global market (Okorie, 2014).

The results of previous research conducted by Dewi (2016) found that entrepreneurial attitudes affect the ability to manage a business. So are the research results of Hardiyanto (2018) found that entrepreneurial attitudes affect interest in Technopreneurship.

Technopreneurship has become a driving force to encourage creativity and maintain a long-term competitive advantage in today's world where economic problems have been combined with increased competitiveness (Brand, 2016). Furthermore, the need to combine the need and need for technology with all elements of entrepreneurship led to the development of the term "Technopreneurship" which refers to new or prospective business ventures that are based on technology (Petti, 2009; Ozgulbas et al, 2013). To achieve business performance goals, the concept of technological entrepreneurship which is understood as a process that involves greater practical use of scientific research findings and modern technology plays an important role.

Lestari et al, (2015) found that the entrepreneurial orientation of marketing performance. Likewise, research results from Kumalaningrum (2012) found that entrepreneurial orientation with technology has a significant effect on business performance.

With digital developments that are happening nowadays, there is a need for innovation that is embedded in the soul of the business actor itself. At Village Owned enterprises in Lombok, the use of computers is not optimal. Human resources who master information technology are very minimal, even though administrative activities and various kinds of documents and reports that have become their daily tasks are increasing. There is still quite a large difference between the performance of one human resource and the performance of other human resources. This difference occurs because some human resources work only to meet the minimum standards that become their culture, while other human resources work actively and in the spirit of devoting themselves to the benefit of the organization.

There are still very few villages implementing digitization in Lombok. This is related to the management of Village Owned enterprises which lacks an entrepreneurial mentality and the ability to utilize technology in business management. When examined further, several other root causes are the cause of the weak performance, namely there are still managers who do not understand their duties and responsibilities. Therefore, Village Owned enterprises must strive to improve the capabilities of its human resources, to achieve optimal performance.

The following are the objectives of this study, namely: 
- Determine the effect of entrepreneurial mental attitudes on the performance of Village Owned enterprises;

- Determine the effect of entrepreneurial mental attitudes on technopreneurship;

- Determine the effect of Technopreneurship on the performance of Village Owned enterprises.

\section{LITERATURE REVIEW}

Performance in English is performance, which means that in Indonesian it is a display (Amir, 2015). There is also a definition of performance as a result of work or work performance. However, performance actually has a broader meaning, not only the result of work but including how the work process takes place. Performance is about doing the job and the results it achieves. Performance is about what is done and how to do it (Wibowo, 2016). Meanwhile, according to Wibowo (2016), performance is an implementation of the plan that has been compiled. Performance implementation is carried out by human resources who have the ability, competence, motivation, and interests.

Another opinion from M Faisal Amir (2015) said that performance is something that is displayed by a person or a process related to assigned work tasks. Performance is not the last end of a series of work processes but an overall appearance that starts from the elements of input activities, processes, outputs, and even outcomes.

Uha (2013) states that there are six elements in entrepreneurial performance:

- Job function results;

- Factors that influence employee performance such as motivation, performance, and role perceptions;

- Achievement of organizational goals;

- A certain period of time;

- Not breaking the law;

- Following morals and ethics.

According to Wibowo (2016), measuring performance needs to be done to find out whether during the implementation of the performance there is a deviation from the predetermined plan, or whether the performance can be carried out according to the specified schedule, or whether the performance results have been achieved as expected. What is measured depends on what stakeholders and customers consider important.

Previous researchers in measuring entrepreneurial performance used the concept of Dwiyanto (2006). In addition, the entrepreneurial performance measures put forward are following the measures used in Village Owned enterprises. Therefore, researchers used the concept of Dwiyanto (2006) in measuring entrepreneurial performance.

Entrepreneurship or entrepreneurship is an intangible culture, a non-physical structural ability that can move a physical figure. Entrepreneurship combines four production factors, namely land, labor, capital, and skills (Sumarsono, 2010). An entrepreneur is someone who decides to start a business, as a franchisor, becomes a franchise, expands a company, buys an existing company or borrows money to produce a new product or offers a new service, and is a manager and people at risk (Saiman, 2015). A superior entrepreneur has creative, innovative, originality, risk-taking, forward-oriented, and prioritizes achievement, resilience, perseverance, not easily discouraged, has high enthusiasm.

An entrepreneurial Attitude is how a person is prepared to respond to the characteristics possessed by an entrepreneur. This is as stated by Suryana (2014), "An entrepreneurial attitude is a person's readiness to respond consistently to the characteristics of an entrepreneur, namely self-confidence, task, and result orientation, risk-taking and likes challenges, leadership, originality, and oriented towards the future". According to Bukhori (2001), the entrepreneurial mentality is a person's attitude in behavior; human beings who have an entrepreneurial mentality have a strong will to achieve their goals and needs in life. Humans who have an entrepreneurial mental attitude have honesty and responsibility. 
The entrepreneurial spirit is the life in entrepreneurship which is basically an entrepreneurial attitude and behavior shown through the nature, character, and character of a person who has a willingness to creatively embody innovative ideas into the real world (Pujiastuti \& Budiarti, 2018). The entrepreneurial spirit is an effort to learn about a person's values, abilities, and behavior to create and innovate (Abbas, 2018). Therefore, the study of entrepreneurship is related to a person's personal values and abilities which are expressed in terms of behavior.

This is in line with what was stated by Day et al in (Ilham, 2018) in principle that entrepreneurial spirit is the nature, characteristics, and character that have the ability to manifest innovative ideas into the real world which are done creatively or in short, are the ability to create the new and different thing, entrepreneurial spirit as a process, with an action-oriented management style that uses innovation and change as the focus of thought and behavior.

The concept of Goeffrey G. Merredith in Suryana (2013) is very synonymous with the attitudes an entrepreneur must-have. Therefore, the researcher used this concept in measuring the attitude of entrepreneurial metal.

According to Winardi (2008), an Entrepreneur means a person who starts (The Originator) a new business venture. Or a manager trying to improve an organizational unit through a series of productive changes. Entrepreneurship is the process of creating something new by exerting time and effort, considering financial, inner strength, and social risks, which in turn will reap satisfying results from independent endeavors (Hisrich Robert $D$, Michael Peter P. \& Shepherd dean A, 2008). An entrepreneur must be good at making innovations to be able to compete and provide satisfaction to his customers.

Meanwhile, the definition of technopreneur according to Arman (2007) is an entrepreneur who builds his business based on his expertise in science and technology and produces innovative products that are useful not only for himself but for the welfare of his nation and country. They are called technopreneurs, namely "modern entrepreneurs" based on technology.

Furthermore, according to Eddy Soeryanto (2010), Technopreneurship (technology entrepreneurship) is part of entrepreneurship that emphasizes technological factors, namely the ability of science and technology in its business processes. The various advances that have been made were initiated with research and new findings in the field of technology which was then developed in such a way as to provide benefits for the creators and the community of users. So the development of business in the field of technology begins with creative ideas in several research centers that can be developed so that it has a selling value in the market.

Utilization of information technology is the behavior or attitude of accountants using information technology to complete tasks and improve their performance. The use of information technology according to Thompson et al in Wijana (2007), namely the use of information technology is the benefit expected by information system users in carrying out their duties or behavior in using technology when doing work. The measurement is based on the intensity of utilization, frequency of use and the number of applications or software used".

The use of information technology is a behavior/attitude to use information technology to complete tasks and improve performance (Nasir and Oktari, 2016). The use of appropriate information technology and supported by the expertise of the personnel who operate it can improve the performance of the company and the performance of the individual concerned.

\section{HYPOTHESIS}

Based on the results of research by Putranto (2013) which proves that entrepreneurial mentality has contributed to the success of small industries. In addition, it is also supported by research by Pujiastuti \& Budiarti (2019), showing the results that entrepreneurial spirit has a positive and significant effect on business performance in Cigondewah Bandung hat center business actors. And other studies also show the same results, namely that entrepreneurial spirit affects the entrepreneurial performance of entrepreneurial students at the Faculty of 
Economics, State University of Semarang. H1: Entrepreneurial Mental Attitude has a positive effect on the Performance of Village Owned Enterprises.

As it is known, one of the characteristics of entrepreneurs is the desire to innovate and the ability to adapt to the times. In today's modern era, the use of information technology to support company operations is nothing new. Based on the results of research conducted by Wati, Sukmawati, \& Alamsyah (2019), it is stated that entrepreneurship learning on entrepreneurial desire (Technopreneur) in students shows a significant effect. Other studies (Ainul, et al, 2016 and Pihie \& Bagheri, 2013) show that student technopreneurs learning has the most significant and positive impact on students' interest in becoming a technopreneur. H2: Entrepreneurial Mental Attitude has a positive effect on Technopreneurship.

Based on the results of research by Erawati \& Wiku (2019) and research by Fajri, M Dian (2011), it shows similar results that the use of information technology has a positive effect on organizational performance. In addition, other research also shows that the information technology linkage has a direct effect on company performance (Nazir \& Oktari, 2011). H3: Technopreneurship has a positive effect on the performance of Village Owned Enterprises.

\section{CONCEPTUAL FRAMEWORK}

The research conceptual framework is intended to provide an overview of the relationship between research variables based on the concepts and theories as well as the empirical conditions described in the literature review above. The conceptual framework of this research is described as follows:

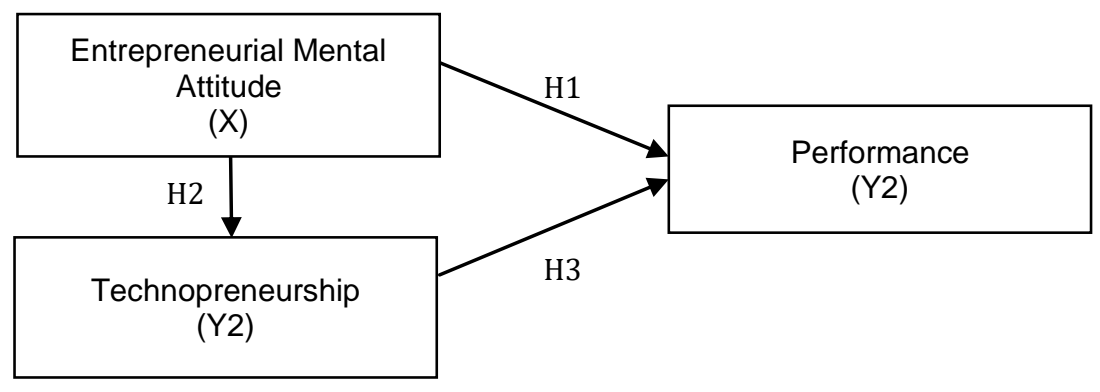

Figure 1 - Research Conceptual Framework

\section{METHODS OF RESEARCH}

This type of research is causal associative. Causal associative research is research that is intended to reveal problems that are causal in nature between two or more variables (Sugiyono, 2017). The object of research in this study was conducted at the Director of Village Owned Enterprises in villages that apply digitization technology as many as 85 Village Owned enterprises. The data collection used in this study was a questionnaire. The quantitative approach used in this analysis is the Partial Least Square (PLS) model. The purpose of using the PLS model in principle is to help researchers to obtain latent variable values for prediction purposes. Meanwhile, the weight estimator to produce latent variable scores is obtained from the specifications of the inner model and outer model, where the inner model is a structural model that connects the indicator (manifest variable) with the construct (latent variable).

\section{RESULTS OF STUDY}

Most of the Directors of Village Owned Enterprises in Lombok Island are male. The dominant jobs in Indonesia are still held by men. Especially for strategic positions such as being a leader in an organization. Therefore, the Directors are still dominated by men 
compared to women. Most Village Owned Enterprises Directors have 1-5 years of experience. The Director on Lombok Island is predominantly appointed by the Village Head, and each Village Head is always changing in every Village Head election. At the same time, the appointment of the Director will follow the term of office of the Village head. In addition, it is stated in the Village regulation that the management period is only 5 years, the extension period is very dependent on its performance. For that reason, Directors have requirements with experience that still need a lot to learn because they are dominated by Directors who have worked under 5 years.

The average score of the Entrepreneurial Mental Attitude based on the response with the 'good' category meaning the Village Owned Enterprises Director on Lombok Island has good character, character, and character in realizing innovative ideas to run a business for the advancement of the Village. The average value of the Technopreneurship score from the respondents' responses with the 'good' category. This means that the Village Owned Enterprises Director has a good ability to apply technology in the process of running the business in Lombok. The average score of the Performance of Village Owned Enterprises with a good category. It mean that Director can produce a good performance in supporting community welfare through independent village economic movements.

To determine the significance level of the path coefficient, the t-value generated by running the Bootstrapping algorithm is used to determine whether the proposed hypothesis is accepted or not. At the 0.05 significance level, the hypothesis will be supported if the $p$-value is less than the critical value, namely $0.05(5 \%)$. The results of the significance level test can be seen in table 1. summarizing the results of hypothesis testing with the PLS approach. The path coefficient value is obtained from the SmartPLS output. The results of the significance can be seen in more detail in the table below,

Table 1 - Model Structural

\begin{tabular}{|c|c|c|c|c|}
\hline Influence Between Variables & Coefficient & T Statistics & P value & Information \\
\hline Entrepreneurial Mental Attitude -> BUMDES performance & 0.425 & 3.884 & 0.000 & Significant \\
\hline Entrepreneurial Mental Attitude -> Technopreneurship & 0.859 & 33.383 & 0.000 & Significant \\
\hline Technopreneurship -> BUMDES performance & 0.441 & 4.106 & 0.000 & Significant \\
\hline
\end{tabular}

Based on Table 1, it explains:

- Entrepreneurial Mental Attitude has a positive and significant effect on the performance, indicated by the path coefficient value of 0.425 with a significance value of 0.000 (lower than the error tolerance of 0.05 ) which means positive and significant so that it can be stated that the first hypothesis is accepted;

- Entrepreneurial Mental Attitude has a positive and significant effect on Technopreneurship, indicated by the path coefficient value of 0.859 with a significance value of 0.000 which means positive and significant, so it can be stated that the second hypothesis is accepted;

- Technopreneurship has a positive and significant influence on the performance, indicated by the path coefficient value of 0.441 with a significance value of 0.000 which means positive and significant, so it can be stated that the third hypothesis can be accepted.

\section{DISCUSSION OF RESULTS}

The Influence of Entrepreneurial Mental Attitudes on Performance. The research results that entrepreneurial mental attitude has a positive and significant effect on the performance of Village Owned enterprises in Lombok Island. This means that the stronger the Entrepreneurial Mental Attitude of the Director, it can be ascertained that the performance of Village Owned Enterprises will be even higher.

Entrepreneurship can be done not only by entrepreneurs but someone who has a spirit, mental and attitude to want to move forward based on creative thinking and can act innovatively, to expand his life and business. Creative and innovative processes are only 
carried out by people who have an entrepreneurial mentality and attitude; namely, people who are confident (confident, optimistic, and full of commitment); take initiative (energetic and confident); have achievement motivation (result-oriented and forward-looking); have a leadership spirit (dare to be different); and brave with challenges.

According to Danarti (2005), to create reliable and successful entrepreneurship, one must have the attitude and mentality of a fighter. This means that to achieve success, a person must have the attitude and mental courage to face the risks that may and will be faced. By using creative and innovative thinking, an entrepreneur must be able to find/obtain and then utilize the potential of resources and funds to produce something new that provides value-added. Optimism and courage must be the main factors of the mental and attitude of an entrepreneur because a pessimist will always find difficulties in every opportunity, while a person who is always optimistic in seeing and running his business will always find opportunities in every difficulty.

The essence of entrepreneurship is how a person can devote all his abilities to create something new and different (create new and different) through creative and innovative thinking to create opportunities. According to Walter D. Scott, the success or failure of a business venture is caused more by a mental attitude than mental capacity. Meanwhile, George Shinn, stated that a positive attitude will not only change a person's life but will also change the world (Danarti, 2005).

BUMDES Director must have the mentality and leadership attitude to show the direction to be taken in running a business, be able to make firm decisions based on selfconfidence and solid thinking, believe in himself, think freely and behave independently. He must always be optimistic in seeing the future of every business that is carried out, and will or may be carried out. Regarding leadership that is in him, it must be quality and dynamic, always looking positively towards the future. Have communication competence, can receive criticism and input, and always be positive towards all opponents and interlocutors. This flexible mental attitude will be able to "pick up" many ideas from work and friends.

The results of this study are in line with the results of research conducted by Putranto (2013) and Alam (2013) which prove that entrepreneurial mental attitudes have a contribution to business success (business performance). In addition, it is also supported by research by Budiarti (2012); Aditya \& Heny 2017); Octavia (2015), and Nurhayati et al (2012), shows that the entrepreneurial spirit has a positive and significant effect on business performance in the business actor of Cigondewah hat center Bandung.

The Influence of Entrepreneurial Mental Attitudes on Technopreneurship. The research results that entrepreneurial mental attitude has a positive and significant effect on Technopreneurship. This means that the stronger the Entrepreneurship Mental Attitude of the Director, implementation of Technopreneurship at Village Owned Enterprises will better.

Technopreneurshipis a process and the formation of new businesses that involve technology as the basis, with the hope that the creation of the right strategies and innovations can someday place technology as one of the factors for business success. According to Technopreneurship.wordpress.com, it is stated that Technopreneurship, by one large part, is still entrepreneurship. The difference is that Technopreneurship is involved in delivering an innovative high technology product or innovatively making use of high technology to deliver its product to consumers or both. The concept of Technoprenerurship as described above basically integrates technology with entrepreneurial skills (entrepreneurship skills). In the concept of Technopreneurship, the basis for entrepreneurial development starts from the existence of inventions and innovations in the field of technology. Technology that is understood in this context is not just technology in the form of high tech, but of course, it does not always have to be technical. Technology can be defined as the application of knowledge to human work. That way the order quantity economy, verbal marketing, and mentoring are well formulated in essence technology as well.

According to Nasution (2007) "A technopreneur is an entrepreneur who is technology savvy, creative, innovative, dynamic, dares to be different and take the unexplored path, and very passionate about their work. They take challenges and strive to lead their life with greater success. They don't fear failing. They take failure as a learning experience, a 
stimulator to look at things differently and stride for the next challenge. Technopreneurs continuously go through an organic process of continuous improvement and always try to redefine the dynamic digital economy ".

From this explanation simply technopreneurs are entrepreneurs who run their business on a technology basis. In other words, Technopreneur is an entrepreneur who optimizes the various potentials of existing technological developments as the basis for developing the business he runs, or you could say this Technopreneur is a technology-based modern entrepreneur in running his business. Meanwhile, Technopreneruship is technology-based entrepreneurship by providing innovation for a product.

The results of this study are corroborating The results of research conducted by Dewi (2016) state that entrepreneurial attitudes have a significant effect on entrepreneurial skills (Technopreneur). Another study from Yani (2014) shows that an entrepreneurial mental attitude can increase the motivation of Technopreneurship which is an innovation for students to do business. Similar findings were also found byMachmud et al, (2020)shows results that people who have an entrepreneurial mentality have the most significant impact on improving technopreneurship.

Influence Technopreneurship on Performance. The research results that Technopreneurship has a positive and significant effect on the performance. Continuous technology is an effort in the field of developing innovation and creativity, especially in information technology, which has become a new target in terms of the real sector. Technopreneurship has opened many jobs for the community in general, of course, can improve the economy of a country, with the support of various parties, it is hoped that technopreneurship can improve the progress of people's welfare.

The development of information technology has had a major impact on society, apart from being able to build advanced and intelligent civilizations and also contributing to the development of the world economy. Therefore it is hoped that people who work in this field can create new fields that are useful for society. One form of innovation that continues to develop, technology that is open resources have been born and provides a forum for innovation for the entire community, with the birth of technology like this, society is not limited by various rules that can hinder creativity, other than not being able to harm anything and can benefit many parties among developments that occurred.

Technological innovation and intense competition in this century have forced companies to change the way they carry out their business activities, to be able to survive in these business activities. To be able to survive in the current conditions forcing companies to change the company's paradigm from the company based on human resources to become a company based on knowledge and technology. When the main goal of the company is the achievement of sustainable business competitiveness, the company management will encourage the process of achieving and developing knowledge and corporate strategy. In terms of company competition, it is also encouraged by the development of technology that is growing rapidly; being left behind in technology will have an impact on the difficulty of winning the competition.

The results of this study are in line with the results of research conducted by Olusegun, Akpoviroro, \& Adebowale, (2019); Adhikara, Lasmy, Sasmoko, \& Indrianti (2019) and Silviasih \& Iskandar. (2016), Show the results that the use of information technology in entrepreneurship (technopreneurship) has a positive effect on organizational performance. In addition, other research, namelyKusumawardhany, Iswadi, Dewi, \& Widjaja (2019) and Adhikara, Lasmy, Sasmoko, \& Indrianti (2019) also show that Technopreneurship has a significant effect on company performance (Nazir \& Oktari, 2011).

\section{CONCLUSION}

The conclusions of the research that can be drawn are:

- An entrepreneurial mental attitude has a positive and significant effect on performance; 
- Entrepreneurial Mental Attitude has a positive and significant effect on Technopreneurship;

- Technopreneurship has a positive and significant effect on performance of Village Owned enterprises.

\section{RECOMMENDATIONS}

Increasing the competitiveness of superior village products through BUMDES can be done with a technology-based entrepreneurship strategy (technopreneurship). Many advantages can be taken by implementing technopreneurship, namely making business processes easier and faster, wider and faster market reach and increasing sales through digital marketing, creating continuous innovation to strengthen competitiveness, and maximizing revenue and profits.

The first stage of technopreneurship in business development is to prepare business owners to become leaders who are motivated, mentally adaptive to current market conditions, creative, and innovative to become agents of change in the face of competition. This is because HR is a key factor in facing the technological era so that socialization and management training for leaders and $\mathrm{HR}$ is needed to prepare HR before carrying out strategic planning.

The next stage is to do creativity and innovation in technology-based production and marketing processes. Machine innovation with the application of appropriate technology will further increase the quantity of production, accelerate the production process, and maintain production quality

Marketing process innovation through digital marketing will help BUMDES in promoting and selling worldwide quickly and efficiently. The innovation of the financial recording process through the mobile application will also make it easier and faster for BUMDES to regularly record financial transactions so that BUMDES can prepare strategic planning for business development with the advantages they have.

\section{REFERENCES}

1. Abbas, D, (2018). The Influence of Business Capital, Market Orientation, and Entrepreneurship Orientation on the Performance of SMEs in Makassar City. Journal of Minds: Management of Ideas and Inspiration

2. Adhikara, C, Lasmy, L, Sasmoko, S, \& Indrianti, Y, (2019). Technopreneurship Skills of Indonesian Entrepreneurs, WoMELA-GG 2019, January 26-28, Medan, Indonesia Copyright $@ 2019$ EAI DOI 10.4108 / eai.26-1-2019.2283128

3. Aditya, A. D. R, \& Heny, K. S. D, (2017). "The Influence of Modernity in Entrepreneurship Attitudes on the Success of Tempe and Tofu MSMEs in Bogor Regency." Agribusiness Forum. Vol. 5. No. 1. 2017.

4. Alias, M. N, Shamsudin, M, Majid, Z. A, \& Hakim, M. N, (2020). Technopreneurship and Digital Era in Global Regulation.

5. Alam, A. P, (2013). The Influence of Experience, Motivation, and Entrepreneurial Mentality on the Success of the Sandal and Shoes Industry in Wedoro. Undergraduate thesis, Faculty of Economics, available athttp://eprints.unjam.ac.id/id/print/4500.

6. Amir, M. F, (2015). Understanding Employee Performance Evaluation, Concepts, and Performance Appraisals in Companies. Jakarta: Mitra WacanaMedia Publisher.

7. Budiarti, (2012). Entrepreneurial Interests Become Entrepreneurs (Studies in Students of the Faculty of Economics, University of Semarang). Semarang: University of Semarang

8. Bukhori, (2001). Entrepreneurship. Bandung: Alfabeta. Arikunto, suharsimi. 2005. Research Management. Jakarta: Rineka Cipta.

9. Dewi, N. L. A, (2016). The Influence of Entrepreneurial Attitudes on the Ability to Manage Business in the Participants of the 2015 UNDIKSHA Entrepreneurial Student Program (PMW). Journal of the Economic Education Study Program (JPPE), 7 (2) .2016 
10. Hisrich, Robert D, Michael P. Peters, and Dean A. Shepherd. 2008. Entrepreneurship Edition 7. Jakarta: Salemba Empat.

11. Jurnali, T, and Supomo, B, (2002). "The Influence of Technology Duty Suitability Factors and Information Technology Utilization on Public Accountant Performance". Indonesian Journal of Accounting Research

12. Ministry of Village, Rural Development and Transmigration, (2019). Strategic Plan, Ministry of Villages, Development of Disadvantaged Areas and Transmigration 20202024, Jakarta: Secretary-General Ministry of Villages, Development of Disadvantaged Areas and Transmigration.

13. Kumalaningrum, M. P, (2012). Business Environment, Entrepreneurship Orientation, Market Orientation, and Performance of Micro, Small, and Medium Enterprises.

14. Kusumawardhany, P. A, Iswadi, H, Dewi, A. D, \& Widjaja, M, (2019). Technopreneurship Strategy: Increasing Competitiveness of Superior Products in the Trawas Region, Mojokerto, National Seminar on Community Service, Sustainable Community Empowerment in terms of the Industrial Revolution 4.0

15. Lestari, S, \& Siswandari, S, \& Riani, A, (2015). "Analysis of the Influence of Entrepreneurship Orientation and Competence Aspects of Knowledge and Skills on Marketing Performance in Pande Besi Craftsmen, Madiun Regency." Journal of Insan Mandiri Education, vol. 1, no. 2, 2015.

16. Machmud, A, Suwatno, Nurhayati, D, Aprilianti, I, \& Fathonah, W. N, (2020). Effect of Self Efficacy ICT on Technopreneurship Intention of Technopreneurial Learning Mediation: The Case Young Generation in Indonesia. Journal of Entrepreneurship Education, 23.

17. Nasution, A. H, Bustanul, A. N, \& Suef, M, (2007). Entrepreneurship. Building a Technopreneurship Spirit, Publisher Andi, Yogyakarta.

18. Nugraha, P, Anggia, J. D, \& Tirtamahya, D. N, (2018). The Influence of Entrepreneurial Spirit and Entrepreneurial Motivation on Business Performance at Binong Jati Bandung Craft Center. FEB Indonesian Computer University: Bandung.

19. Nurhayati, P, Sarianti, T, \& Muflikh, Y. N, (2012). Analysis of the Influence of Entrepreneurial Characteristics to The Performance of Small Scale Agribusiness Enterprises in West Java.

20. Nasution, A. H, (2007). Entrepreneurship: Building a Technopreneur Spirit. Yogyakarta: Andi Publisher.

21. Nurfitriya, M, (2018). The Influence of Entrepreneurial Attitudes on the Business Development of Batik Entrepreneurs in the Batik Craft Center of Tasikmalaya City, Journal of Economic Education, Vol. 11, No.1, 2018 page 1-08, DOI: https://dx.doi.org /10.17977/UM014v11i12018p001

22. Octavia, J, (2015). The Influence of Entrepreneurial Attitudes and Entrepreneurial Competence on Business Success (Survey on Cibaduyut Shoe Manufacturers, Bandung City). Journal of Accounting Research VII (1), 41-59

23. Olusegun, O. O, Akpoviroro, K. S, \& Adebowale, O. M, (2019). Impact of Technopreneurship on Business PerformanceJournal of Economics and Management Research. Vol. 8, 2019, https://doi.org/10.22364/jemr.8.03

24. Rahmawati, D, (2008). "Analysis of Factors Affecting the Utilization of Information Technology". Vol.5, no. 1. Journal of Economics and Education.

25. Silviasih, Slamet and Iskandar, (2016). The Influence of Market Orientation and Entrepreneurship Orientation on Business Performance on Garment Manufacturing Sector SME Owners in Tanah Abang, Central Jakarta. Business Management Scientific Journal Vol. 16 No.1.

26. Siregar, A. H, and Suryanawa, I. K, (2009). "Utilization of Information Technology and its influence on Individual Performance at Suryana. (2006). Entrepreneurship. Jakarta: Four Salemba.

27. Suliyanto, (2006). Business Research Methods. Yogyakarta: Andi.

28. Sahabuddin, (2015). Improving the Performance of Micro, Small, and Enterprises. Intermediate in Entrepreneurship Persperktif, 1st Edition, Caravaca, Makassar. R. 
29. Soegoto, E. S, (2010). Entrepreneurship Becomes an Excellent Businessman. (revised edition). Kompas Gramedia. Jakarta.

30. Sugiyono, (2005). Understanding Qualitative Research. Bandung: CV. Alfabeta.

31. Sugiyono, (2017). Quantitative Research Methods, Qualitative, R \& D. Bandung: CV. Alfabeta.

32. Sumarsono, S, (2010). Entrepreneurship. Yogyakarta: Graha Science.

33. Suryana, (2013). The Economic Creative, the New Economy: Changing Ideas and Creating. Opportunity. Jakarta: Four Salemba.

34. Welsh, H, (2019). The Influence of Entrepreneurship on Business Capability and Business Performance of Padang Restaurant, in the Special Region of Yogyakarta, Equity Vol. 13 No. 3 September 2009: 371 - 387.

35. Windy, M, (2009). Entrepreneurship Success Story Approach. Surakarta: LPP UNS.

36. Wibowo, (2016). Performance Management, Fifth Edition, PT.Rajagrafindo Persada. Jakarta-14240.

37. Wijaya, N, (2007). Utilization of Information Technology and Its Influence on Rural Banks in Tabanan Regency. Journal. Udayana University: Bali

38. Winardi, J, (2008). Entrepreneur \& entrepreneurship. Jakarta: Golden

39. Wiranto, M, (2001). Introduction to Entrepreneurship (Basic Framework for Entering the World of Business). Yogyakarta: BPFE-Yogyakarta.

40. Yani, R. A, (2014). Increasing Motivation for Technopreneurship as a Potential for Student Innovation for Doing Business,http://eprints.binadarma.ac.id/id/eprint/2082

41. Yuliana, R, \& Pujiastuti, Y, (2018). Entrepreneurship Orientation, Market Orientation and Business Strategy for Business Performance. Tirtayasa Ekonomika. 